\title{
The implications of selective logging and forest fragmentation for the conservation of avian diversity in evergreen forests of south-west Ghana
}

\author{
LARS H. HOLBECH
}

\section{Summary}

The urgent global objective of developing sustainable tropical forestry management practices, which also target biodiversity conservation, requires rapid comparative studies that address both biogeography and logging practices. This paper examines avifaunal implications (focusing on species diversity and composition) of forest fragmentation and selective logging, by comparing 15 selected reserved forests in south-west Ghana. The regeneration time since last logging varied from o (logging continuing) to 21 years, with one unlogged site as control. Extraction levels ranged between 0.20 and 3.75 trees per ha (mean 0.90). Bird sampling involved understorey mist-netting and standardized line-transect walks, which respectively accumulated 8,348 captures and 22,452 single records of 147 species. Mist-net data showed that understorey bird diversity was positively correlated with logging intensity up to $c .3$ trees per ha, reflecting increased influx of open-land species and a persistence of forest obligates during the first 5 years after logging. The overall abundance of forest interior species tended to decrease 5-10 years after logging, but recovered fairly well thereafter. Canopy birds were generally more loggingresilient. Rare forest obligates with high conservation importance were found to be equally abundant in virgin and logged, large forests, whereas these birds were poorly represented in small heavily logged forests. The results are compared with findings from other regions, and conservation implications and constraints are discussed in a global perspective. Finally, recommendations on size-related sustainable extraction levels and regeneration time are presented for the Upper Guinea Forest.

\section{Introduction}

The impacts of habitat fragmentation and logging disturbance on tropical forest avifaunas have gained much attention from conservation biologists around the world for the past two decades, e.g. in Brazil (Johns 1991, Bierregaard and Lovejoy 1989, Aleixo 1999), Belize (Whitman et al. 1998), French Guyana (Thiollay 1992, 1997), Venezuela (Mason 1996), New-Guinea and Australia (Bell 1982, Driscoll and Kikkawa 1989), India (Datta 1998), Indonesia (Wilson and Johns 1982, Marsden 1998), Malaysia (Johns 1985, 1986, 1987, 1988, 1989, 1992, 1995, Grieser Johns 1996, Lambert 1991, 1992, Wong 1985, 1986), Kenya (Fanshawe 1996), Uganda (Dranzoa 1993, 1995, 1998, Owiunji and Plumptre 1998, Dale et al. 2000, Owiunji 2000) and Tanzania (Newmark 1991, Fjeldså and Rabøl 1995, Fjeldså 1999). There are a number of published long- and short-term intensive studies from South America, South-East 
Asia and East Africa. However, few data originate from central and western African bio-geographic areas.

Except for a few studies (Whitman et al. 1998, Aleixo 1999, Owiunji and Plumptre 1998, Owiunji 2000), the general consensus is that selective logging has a detrimental impact on vegetation structure and consequently on overall diversity and rarities. Although Johns (1992, 1995) derived some general conservation implications from his extensive Malaysian experience, management applications in the form of tangible recommendations on sustainable upper limits to extraction levels and lower limits on regeneration cycles are, on the whole, not attempted. The question for conservation biologists, therefore, is whether to wait 50 or 100 years to assess the impacts on carefully monitored sites before making appropriate recommendations based on experimentally correct designs, or whether to make comparative analyses of the present state and provide national forestry services with realistic interventions on more sustainable logging practices which are region-specific and take account of area and degree of isolation. The latter approach has recently been used by Marsden (1998) and Aleixo (1999), whilst the former strict scientific and academic approaches are often inappropriate in resource-starved Africa.

A previous unpublished short-term study from the moist evergreen Bia rainforest (MAB reserve) in south-west Ghana found low-extraction selective logging ( $1-2$ trees per ha), as is being practised in this easternmost part of the Upper Guinea Forest, tended to be relatively sustainable regarding conservation of vulnerable forest obligates (Holbech 1992). However, these preliminary findings required a more thorough study, particularly as they stood rather uniquely amongst the generally negative experiences from elsewhere in Africa, South-East Asia and the Neotropics. This study addresses four major questions: (I) Do the preliminary findings from Bia apply to the entire evergreen forest zone of the Upper Guinea Forest, with particular reference to Ghana? (2) What is the relationship between logging intensity and avian diversity/ rarity? (3) What is the relative importance of disturbance from logging operations compared with size and degree of isolation of a forest area? (4) Why do the findings from Ghana contrast with the rather negative evidence regarding selective logging found elsewhere? Finally, the local and global conservation implications and constraints of the findings are discussed, and recommendations for further conservation improvement of logging practices in Ghana and the Upper Guinea Forest are presented.

\section{Study area}

A total of 15 protected forest areas in the Western Region of Ghana were selected, covering wet evergreen (WE) and moist evergreen (ME) high forest zones (Hall and Swaine 1976). The two zones differ only slightly in precipitation and forest structure. The WE zone receives c. $2,000 \mathrm{~mm}$ or above of rain annually and the closed canopy reaches an average height of $30-35 \mathrm{~m}$, whereas the ME zone gets some $1,750-2,000 \mathrm{~mm}$ rainfall per year and has a slightly discontinuous average canopy of $35-40 \mathrm{~m}$. Both faunal and floral diversity are higher in the WE zone, although the majority of large vertebrates occur in both zones. All selected forest sites lie in a lowland area with altitudes of 25-150 m, with a few hilltops up to $300 \mathrm{~m}$.

The 15 areas consisted of 14 forest reserves (FRs) and one resource reserve $(\mathrm{RR})$, respectively under Ghana Forestry Commission and Ghana Wildlife Division jurisdiction (Figure 1, Table 1). FRs function primarily as timber resources and 


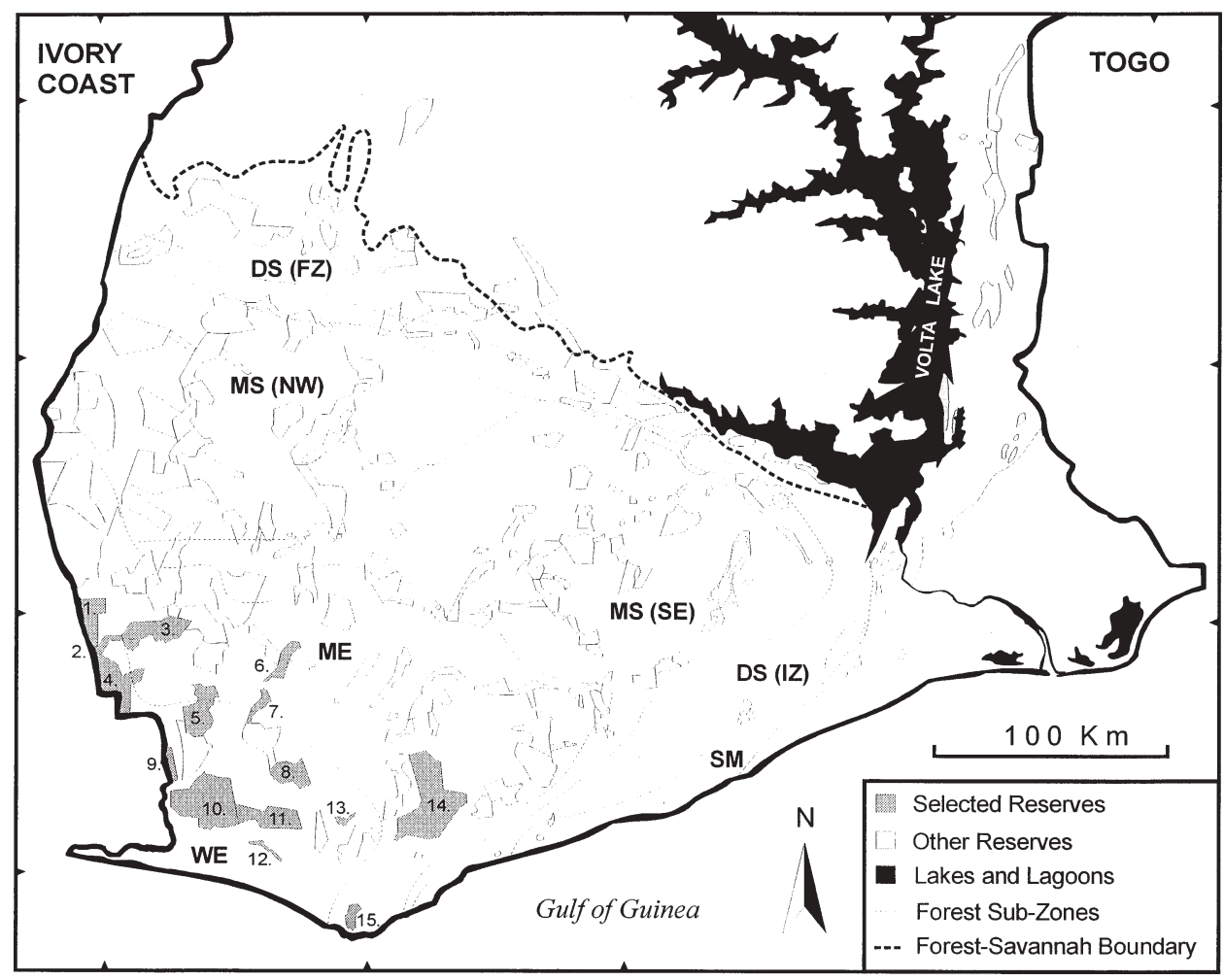

Figure 1. The high forest of south-west Ghana, with sub-zones, protected reserves and selected study areas. Sub-zones (after Hall and Swaine 1976): WE, wet evergreen; ME, moist evergreen; MS, moist semi-deciduous; DS, dry semi-deciduous; SE, south-east; NW, north-west; FZ, fire zone; IZ, inner zone; SM, southern marginal. Study areas: 1 , Dadiaso FR; 2, Disue FR; 3, Yoyo FR; 4, Boin FR; 5, Tano Nimri FR; 6, Bura FR; 7, Mamiri FR; 8, Fure FR; 9, Jema-Assemkrom FR; 10, Ankasa RR/Nini-Suhien NP; 11, Draw FR; 12, Ebi FR; 13, Neung North FR; 14, Subri FR; 15, Cape Three Point FR.

practically all are subject to selective logging. Ankasa RR has been strictly protected against commercial logging since its revocation from FR in 1976. The size of the reserves studied ranged from $25.9 \mathrm{~km}^{2}$ to $587.9 \mathrm{~km}^{2}$, logging period from 1 to 25 years with regeneration periods from o (continuing logging) to 21 years. The JemaAssemkrom FR has never been commercially logged, and serves as a virgin control site. Three other forests - Ankasa RR, Dadiaso FR and Disue FR - have been subject only to minor roadside felling of a few, large, highly valuable timber species ("salvage" felling), e.g. Khaya ivorensis and Tieghemella heckelii. The 15 forests were surveyed consecutively during a 2-year period between 11 September 1993 and 8 August 1995 .

\section{Methods}

\section{Assessment of logging intensity}

Visible signs of logging activity were recorded along all cut transects. Four main signs were considered: ( 1 ) skid tracks and (2) hauling roads that crossed a transect or were 


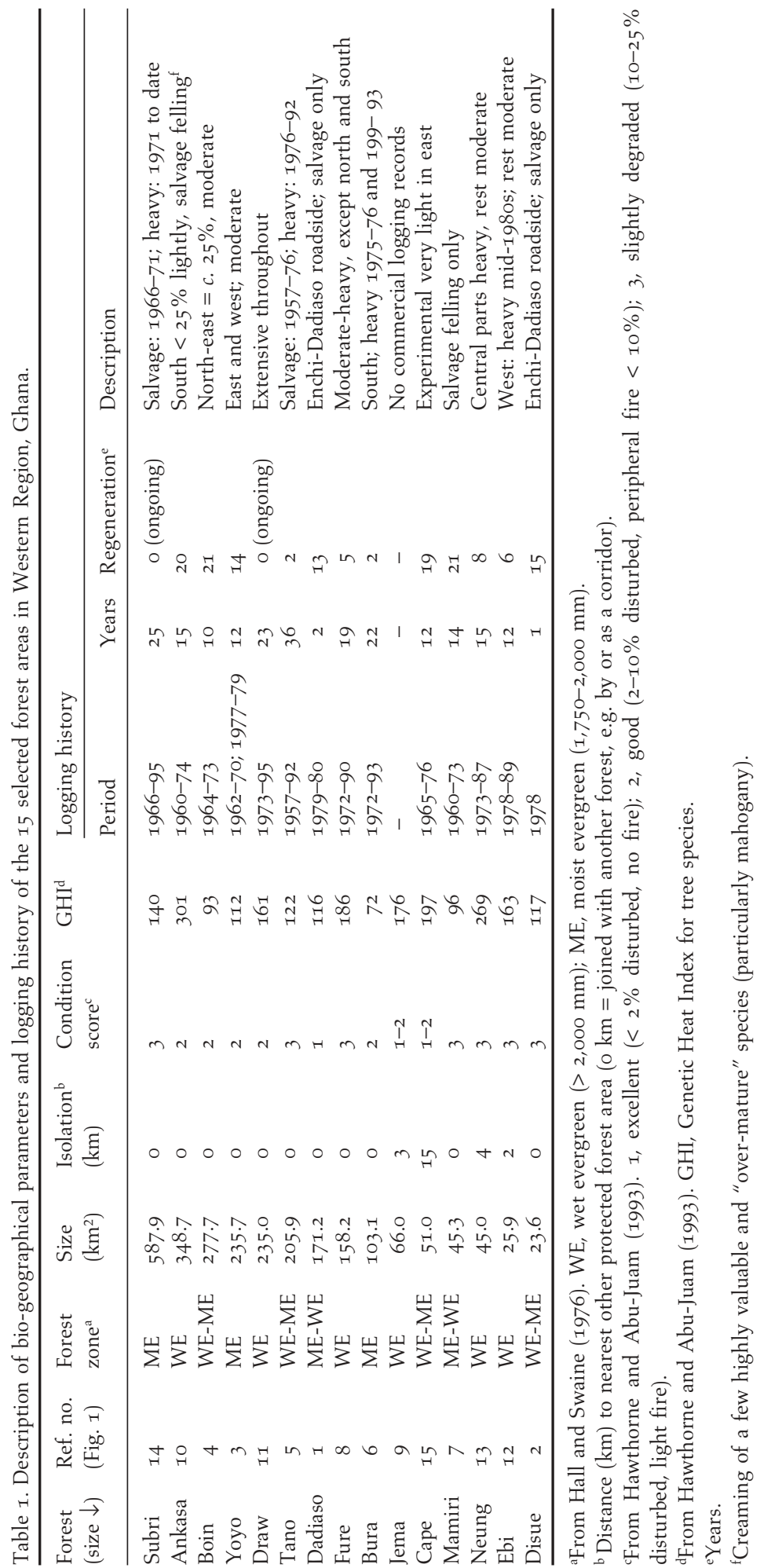


detected within 5-10 $\mathrm{m}$ on either side of it, (3) logs or stumps found within c. $5 \mathrm{~m}$ on either side of a transect, and (4) loading bases that crossed transects or were detected within 5-10 $\mathrm{m}$ on either side. Logs and stumps were more difficult to detect in the often dense undergrowth of recently $(<5-10$ years old) logged forests. The number of stems and stumps found per $\mathrm{km}$ of transect reflected the minimum extraction level recorded on a $I$ ha strip of forest ( $10 \mathrm{~m} \times 1$,OOO $\mathrm{m}=1$ ha). As some stumps and logs may have been missed due to poor visibility, the true extraction levels may have been some $10 \%$ higher in certain recently logged forests, particularly where the colonizing Chromolaena odorata is widespread.

To quantify the overall impact of logging on vegetation cover, the four parameters were given a weighted score according to the mean ground area they disturb. References of mean ground disturbance were taken from the Ghana Logging Manual (Ghana Forestry Department 1992) and Adams et al. (1994). Thus, skid tracks (timberjack and bulldozer) were set at $5 \mathrm{~m}$, hauling roads (timber truck) at $10 \mathrm{~m}$, felling gaps (equal one stump or stem) at $25 \mathrm{~m}$, and loading bases (log stations) at $50 \mathrm{~m}$ in diameter or across. The scores for each of the four parameters were calculated as single records per $\mathrm{km}$ of transect multiplied by a factor 5, 10, 25 or 50 respectively. The sum of the four weighted scores represented the logging index (LI) for each forest, based on the sum of all logging sign records from the transects surveyed in that particular forest.

\section{Mist-netting of understorey birds}

Mist netting is a very effective method for detecting the presence of understorey birds, particularly those that are likely to be missed by audio-visual counts because of their behaviour (e.g. cryptic, shy and silent species). The method, however, is strongly biased towards the lower strata and cannot be used to census whole forest bird communities (Remsen and Good 1996). Furthermore, as the area sampled cannot be quantified, mist-net data can only provide relative abundance indices rather than absolute densities (Mason 1996). An advantage, however, is that sampling is repeatable and has no observer biases (Karr 1982). Moreover, mist-netting does not rely on assumptions on territoriality, unlike many observer methods (Mason 1996).

Mist-nets were set 5-10 $\mathrm{m}$ on each side of the transects. Three net-lengths were used, preferably $12 \mathrm{~m}$, secondarily $9 \mathrm{~m}$, and $6 \mathrm{~m}$ only at narrow passages in dense vegetation. Nets were four-shelved, with a $15 \mathrm{~mm}$ mesh, and 2.7 or $3.2 \mathrm{~m}$ high. The lowest shelf was normally set $20-30 \mathrm{~cm}$ above the forest floor. A total of $10-12$ nets were operated simultaneously, giving a range of from 90 to $126 \mathrm{~m}$ of net in use. Nets were spaced at intervals of 100 or $150 \mathrm{~m}$ along each transect and kept open (closed during rains) from 06 hoo-06h3o to 17 hoo-18h3o and were inspected regularly. To reduce recaptures and net shyness, nets were moved every $2-4$ days, according to the bird activity encountered. Birds were not banded but marked with a coloured permanent-ink pen, for recapture detection purposes.

\section{Line transects}

Censuses were conducted alongside mist-netting on the same transects. As other team members opened mist-nets in the morning, the author recorded birds along transects, 
traversing on foot at a slow steady speed of $c .1 \mathrm{~km} / \mathrm{h}$. At the end of the line a pointcount was made for $1-1 \frac{1}{2}$ hours, adding records to the walking census with only one record per species recorded at the point-count, irrespective of how many times it was seen or heard. Following first net inspections, bird records were still added to the early morning census. Hence, a single morning census covered the period from $c$. o6hoo to oghoo. Afterwards, any new species not heard in the morning session were recorded, with only one record per each new species, irrespective of how many times it was seen or heard. This procedure was carried out on all transects in all forests.

Generally, birds could be visually detected up to $c .25 \mathrm{~m}$ on each side of the transect depending on vegetation visibility at different strata. Bird calls and song could be detected up to $c .50 \mathrm{~m}$ on each side and vertically upward. Vocal records were the main data source and were used to detect species presence and assess relative abundance. Clear sightings were rare and often time-consuming to obtain. Vocalizations produce a reliable rapid survey of the avifauna, irrespective of vegetation structure, strata and other factors determining visibility. Only very secretive and elusive understorey and silent top-canopy species were missed using this method. Aerial birds spending most of their time above the canopy (i.e. swifts and swallows) were not included in this survey.

\section{Data analysis}

Sampling effort for each forest varied according to size and accessibility. As sampling effort was unequal among forests, observed species richness $\left(\mathrm{S}_{\mathrm{obs}}\right)$ could not simply be compared, because sampling effort (i.e. number of individuals, $\mathrm{N}_{\text {tot }}$ ) was positively correlated with $\mathrm{S}_{\mathrm{obs}}$ (Figure 2). To rectify $\mathrm{S}_{\mathrm{obs},}$ a rarefaction procedure (Monte Carlo Simulation) was applied to both mist-net and transect data sets. Therefore, $\mathrm{S}_{\text {obs }}$ values were "calibrated" according to the forest with least sampling effort (Disue FR). In the rarefaction procedure five samples were taken for each forest from which the mean value was obtained, i.e. the calibrated species number $\left(\mathrm{S}^{*}\right)$. This S-transformation statistically justifies a direct comparison of $S^{*}$ in relation to the four variable disturbance factors related to logging (intensity and regeneration time) and fragmentation (size and distance to nearest neighbouring forest). To test the correlation between avian diversity/rarity ( $\mathrm{S}^{*} ; \mathrm{CSI}=$ conservation importance) and the four independent variables on logging and fragmentation, a four-way ANOVA was applied using SAS.

a)

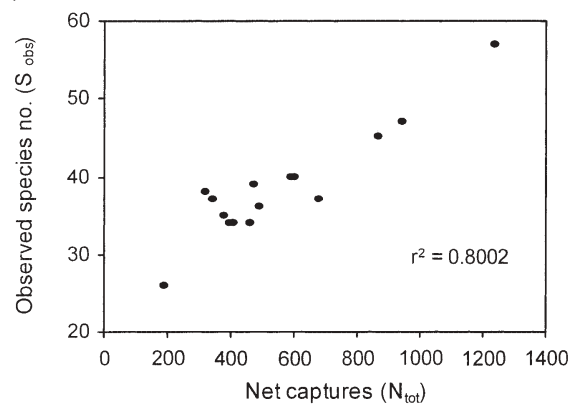

b)

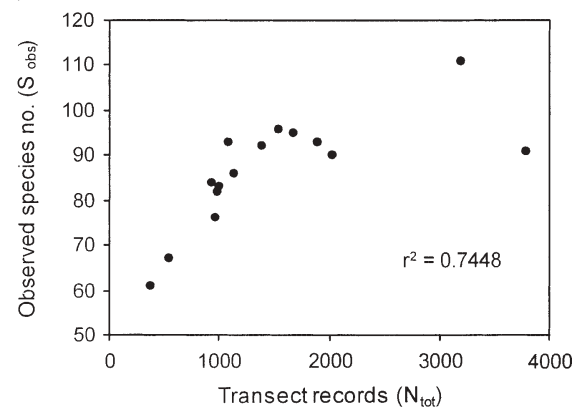

Figure 2. Correlation between sampling efforts $\left(\mathrm{N}_{\text {tot }}\right)$, i.e. number of individuals netted $(a)$ or recorded $(b)$ and total observed species number $\left(\mathrm{S}_{\text {obs }}\right)$ for 15 forests in Western Region, Ghana. 
Table 2. Recorded logging signs and derived logging index (LI) for the 15 selected forest areas in Western Region, Ghana. Number of logs/stumps per km equals minimum extraction level, i.e. trees per ha (italicized column). Figures in parentheses refer to the estimated average relative loss of vegetation in $\mathrm{m}$ on a transect.

\begin{tabular}{|c|c|c|c|c|c|c|c|c|c|}
\hline \multirow[t]{2}{*}{ Forest (LI $\downarrow$ ) } & \multicolumn{2}{|c|}{$\begin{array}{l}\text { Skid tracks } \\
\text { (width }=5 \mathrm{~m} \text { ) }\end{array}$} & \multicolumn{2}{|c|}{$\begin{array}{l}\text { Hauling roads } \\
\text { (width = } 10 \mathrm{~m} \text { ) }\end{array}$} & \multicolumn{2}{|c|}{$\begin{array}{l}\text { Logs/stumps } \\
(\text { gap }=25 \mathrm{~m})\end{array}$} & \multicolumn{2}{|c|}{$\begin{array}{l}\text { Loading bases } \\
(\text { diam. }=50 \mathrm{~m})\end{array}$} & \multirow[t]{2}{*}{ LI } \\
\hline & per km & score & per km & score & per $\mathrm{km}$ & score & per $\mathrm{km}$ & score & \\
\hline Bura & $7 \cdot 50$ & $37 \cdot 50$ & o & o & 3.75 & 93.75 & o & o & 131.3 \\
\hline Draw & 3.43 & 17.15 & 0.29 & 2.90 & 1.62 & 40.50 & o & o & 60.6 \\
\hline Fure & 1.45 & 7.25 & 0.26 & 2.60 & 1.71 & 42.75 & 0.13 & 6.50 & 59.1 \\
\hline Subri & 3.55 & $17 \cdot 75$ & 0.37 & 3.70 & 1.50 & $37 \cdot 50$ & o & o & 59.0 \\
\hline Tano Nimri & 2.29 & 11.45 & 0.83 & 8.30 & 1.04 & 26.00 & o & o & 45.8 \\
\hline Boin & 0.67 & $3 \cdot 35$ & 0.38 & 3.80 & 0.48 & 12.00 & 0.48 & 24.00 & 43.2 \\
\hline Neung North & o & $\mathrm{o}$ & o & o & 1.43 & $35 \cdot 75$ & $\mathrm{o}$ & o & 35.8 \\
\hline Үoyo & 1.33 & 6.65 & 0.22 & 2.20 & $o$ & o & 0.22 & 11.00 & 19.9 \\
\hline Ankasa & 0.41 & 2.05 & 0.14 & 1.40 & 0.20 & 5.00 & 0.20 & 10.00 & 18.5 \\
\hline Mamiri & 2.05 & 10.25 & o & $\mathrm{o}$ & 0.26 & 6.50 & o & o & 16.8 \\
\hline Ebi & 1.00 & 5.00 & o & $\mathrm{O}$ & 0.20 & 5.00 & o & o & 10.0 \\
\hline Dadiaso & 0.20 & 1.00 & O & o & 0.20 & 5.00 & O & o & 6.0 \\
\hline Cape Three Point & o & o & o & $\mathrm{O}$ & 0.20 & 5.00 & $\mathrm{O}$ & o & 5.0 \\
\hline Jema-Assemkrom & o & o & o & o & $o$ & o & o & o & 0.0 \\
\hline Disue & $\mathrm{O}$ & $\mathrm{o}$ & $\mathrm{O}$ & $\mathrm{O}$ & $o$ & $\mathrm{O}$ & o & o & 0.0 \\
\hline
\end{tabular}

\section{Results}

\section{Logging intensity}

Mean minimum extraction levels based on log/stump counts was 0.90 trees per ha (range 0-3.75) (Table 2). Three forests had extraction levels $>1.50$ trees per ha (heavily logged), three of $0.50-1.50$ trees per ha (moderately logged), nine with $<0.50$ trees per ha (lightly logged), and two with no signs of logging recorded (Disue and Jema-Assemkrom).

The positive linear correlation between calculated LI and minimum extraction level was highly significant $\left(r^{2}=0.941, P<0.001, d f=14\right.$; Figure $\left.3 a\right)$. The positive correlation between LI and logging period (Figure $3 \mathrm{~b}$ ), and the negative correlation between LI and regeneration time (Figure 3c) were also significant, whereas the LI area plot was insignificant (Figure $3 \mathrm{~d}$ ). Therefore, the LI was a good descriptor of the actual logging history, and the linear relation between LI and tree extraction was approximately: $\mathrm{LI}=33 \times$ trees extracted per ha +6 . It is also evident that there was no direct relation between LI and forest size.

\section{Species richness and logging intensity}

A total of 325 days were used netting birds (total c. 327,000 net-metre-hours $(\mathrm{n}-\mathrm{m}-\mathrm{h})$ ), and c. $319 \mathrm{~km}$ were walked along the $c .91 \mathrm{~km}$ of cut transects over 237 days (Table 3 ). Species richness $\left(\mathrm{S}^{*}\right)$ for understorey birds (net data) increased with logging intensity up to $c .3$ trees per ha $(\mathrm{LI}=100)$, after which diversity declined (Table 4 , Figure 4a: $r^{2}=0.7924, \quad P<0.001 ; \quad d f=13, n=15 ; \quad$ ANOVA: $F=5.52, \quad P<0.0159$; $\mathrm{df}=4$ ). In contrast transect data showed no significant correlation between LI and $S^{*}$ (Table 4, Figure $4 \mathrm{~b}: r^{2}=0.203, P>0.05 ; \mathrm{df}=13, n=15$ ). 
a)

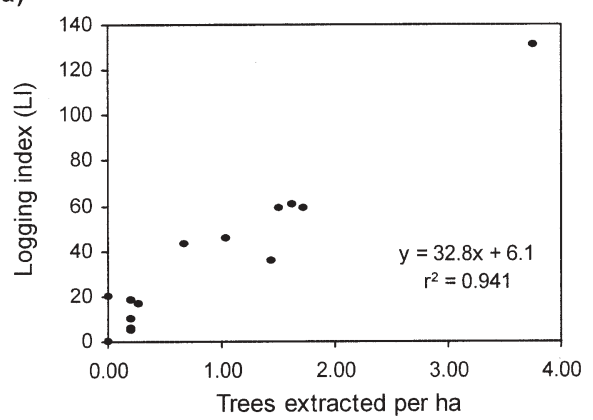

c)

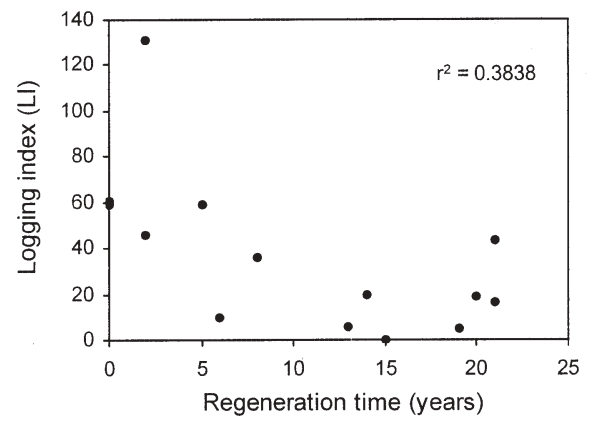

b)

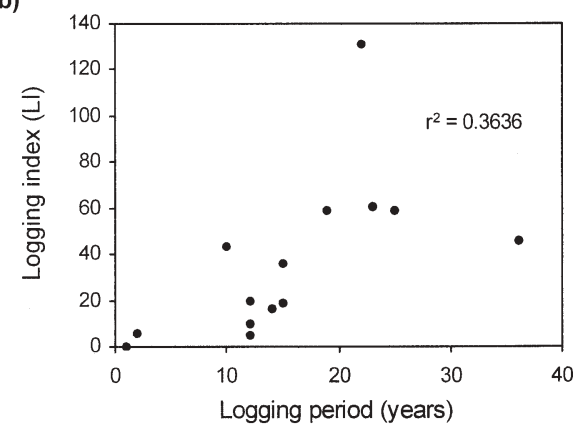

d)

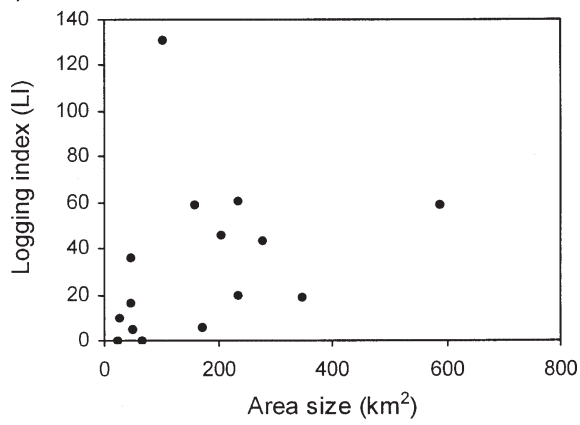

Figure 3. Correlation between calculated logging index (LI) and (a) derived minimum extraction levels, (b) logging period, (c) regeneration time, and $(d)$ area size for 15 forests in Western Region, Ghana.

\section{Species richness and regeneration time}

Mist-net data suggested that there was an initial increase in species richness in the first 5 years after logging, followed by 5-15 years in which it decreased, after which it increased steadily, reaching pre-logging levels after 20-25 years (Figure 5a: $\left.r^{2}=0.5461, P<0.01 ; \mathrm{df}=12, n=14\right)$. The pattern for transect data was less clear and not significant (Figure $5 \mathrm{~b}$ ).

\section{Species richness and size of forest area}

Mist-net data showed no significant correlation between $S^{*}$ and size of the forest (Figure 6a). In contrast, transect data (Figure 6b) showed a pronounced relationship between area and species richness (four-way ANOVA: $r^{2}=0.4478, P<0.01 ; \mathrm{df}=13$, $n=15)$.

Summarizing the comparison of mist-net and transect data, it is evident that logging had a more pronounced effect on understorey birds. The short-term positive effect on understorey species richness by moderate logging intensities, and the fact that larger heavily logged forests had higher species richness than lightly logged or even virgin smaller forests, highlights the importance of area compared with logging damage to vegetation structure per se. Similarly, it appeared that after 20-25 years of forest regeneration logged forests were equally or more species-rich, compared with the pre-logged state of similar forests. 
Table 3. Avifaunal sampling efforts for 15 selected forests in Western Region, Ghana.

\begin{tabular}{|c|c|c|c|c|c|c|}
\hline \multirow[t]{2}{*}{ Forest (size $\downarrow$ ) } & \multicolumn{2}{|c|}{ Transects } & \multicolumn{2}{|c|}{ Line-transect walks } & \multicolumn{2}{|c|}{ Mist-netting } \\
\hline & no. & $\mathrm{km}$ & days & $\mathrm{km}$ & days & n-m-h \\
\hline Subri & 4 & $5 \cdot 4$ & 9 & 12.0 & 13 & 16,702 \\
\hline Ankasa & 10 & 14.8 & 38 & 62.5 & 62 & 25,775 \\
\hline Boin & 5 & 10.5 & 30 & 46.7 & 42 & 41,714 \\
\hline Yoyo & 3 & $4 \cdot 5$ & 14 & 21.6 & 17 & 16,899 \\
\hline Draw & 8 & 10.5 & 24 & 30.1 & 32 & 40,772 \\
\hline Tano Nimri & 3 & 4.8 & 15 & 17.6 & 19 & 23,057 \\
\hline Dadiaso & 4 & $4 \cdot 9$ & 23 & $25 \cdot 9$ & 24 & 20,346 \\
\hline Fure & 6 & 7.6 & 19 & 24.1 & 25 & 31,301 \\
\hline Bura & 3 & $4 \cdot 0$ & 10 & 12.8 & 13 & 16,105 \\
\hline Jema-Assemkrom & 3 & $4 \cdot 5$ & 14 & 11.7 & 18 & 20,551 \\
\hline Cape Three Point & 4 & 5.0 & 9 & 11.4 & 14 & 17,375 \\
\hline Mamiri & 3 & 4.0 & 10 & 12.8 & 13 & 16,173 \\
\hline Neung North & 3 & 2.8 & 6 & 8.4 & 8 & 10,261 \\
\hline Ebi & 4 & 5.0 & 11 & 13.8 & 15 & 19,345 \\
\hline Disue & 2 & 3.0 & 5 & $7 \cdot 5$ & 10 & 10,633 \\
\hline Total & 65 & $91 \cdot 3$ & 237 & 318.9 & 325 & 327,009 \\
\hline
\end{tabular}

Table 4. Total net-captures and transect records $\left(\mathrm{N}_{\text {tot }}\right)$, overall capture and recording rate $\left(\mathrm{N}_{\text {fre }}\right)$, observed species number $\left(\mathrm{S}_{\mathrm{obs}}\right)$ and calibrated species richness $\left(\mathrm{S}^{*}\right)$ for 15 selected forests in Western Region, Ghana.

\begin{tabular}{|c|c|c|c|c|c|c|c|c|}
\hline \multirow[t]{2}{*}{ Forest (LI $\downarrow$ ) } & \multicolumn{4}{|c|}{ Mist-net data } & \multicolumn{4}{|c|}{ Transect-walk data } \\
\hline & $\mathrm{N}_{\text {tot }}$ & $\mathrm{N}_{\text {fre }}$ & $\mathrm{S}_{\mathrm{obs}}$ & $\mathrm{S}^{*}$ & $\mathrm{~N}_{\text {tot }}$ & $\mathrm{N}_{\text {fre }}$ & $\mathrm{S}_{\mathrm{obs}}$ & $S^{*}$ \\
\hline Bura & 318 & 0.0197 & 38 & 31.6 & 1,001 & 78.2 & 83 & 66.0 \\
\hline Draw & 944 & 0.0232 & 47 & 31.6 & 1,896 & 63.0 & 93 & 66.0 \\
\hline Fure & 600 & 0.0192 & 40 & 29.8 & 1,532 & 63.6 & 96 & 65.2 \\
\hline Subri & 468 & 0.0280 & 39 & 29.6 & 1,079 & 89.9 & 93 & 70.6 \\
\hline Tano Nimri & 586 & 0.0254 & 40 & 30.2 & 1,664 & 94.6 & 95 & 70.4 \\
\hline Neung North & 374 & 0.0364 & 35 & 29.0 & 534 & 63.6 & 67 & 58.6 \\
\hline Boin & 1,236 & 0.0296 & 57 & 30.2 & 3,186 & 68.2 & 111 & 74.8 \\
\hline Yоуо & 460 & 0.0272 & 34 & $27 \cdot 4$ & 1,391 & $64 \cdot 4$ & 92 & 69.2 \\
\hline Ankasa & 863 & 0.0335 & 45 & 29.6 & 3,782 & 60.6 & 91 & 66.2 \\
\hline Mamiri & 343 & 0.0212 & 37 & 29.8 & 933 & 72.9 & 84 & 67.6 \\
\hline Ebi & 490 & 0.0253 & 36 & $27 \cdot 4$ & 1,130 & 81.9 & 86 & 66.0 \\
\hline Dadiaso & 395 & 0.0194 & 34 & 27.0 & 2,020 & 78.0 & 90 & 67.8 \\
\hline Cape Three Point & 676 & 0.0389 & 37 & 26.4 & 955 & 83.8 & 76 & 60.4 \\
\hline Jema-Assemkrom & 406 & 0.0198 & 34 & 27.0 & 986 & $84 \cdot 3$ & 82 & 68.4 \\
\hline Disue & 189 & 0.0178 & 26 & 26.0 & 363 & 48.4 & 61 & 58.0 \\
\hline Total or Average & 8,348 & 0.0255 & 85 & & 22,452 & 70.4 & 133 & \\
\hline
\end{tabular}

$\mathrm{N}_{\text {fre, }}$ bird captures per $\mathrm{n}-\mathrm{m}-\mathrm{h}$, or bird records per $\mathrm{km}$ of walked transect.

\section{Distribution of forest obligates and open-land species}

To determine whether the positive relationship between logging intensity and understorey species richness was a result of increased influx of open-land species, all species were classified into three categories (see Appendix): (I) forest obligates (Fs) dependent on the closed-canopy forest interior, (2) open-land species (Os) with high 
a)

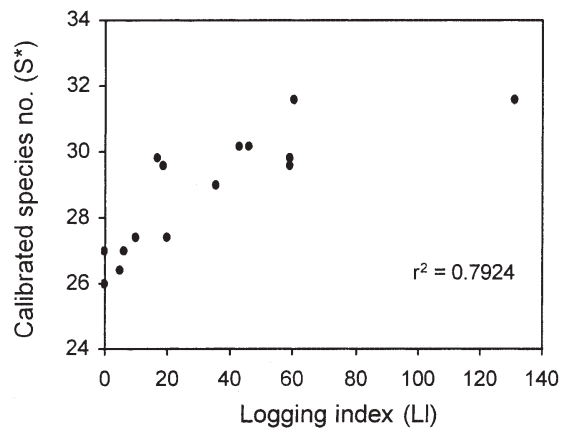

b)

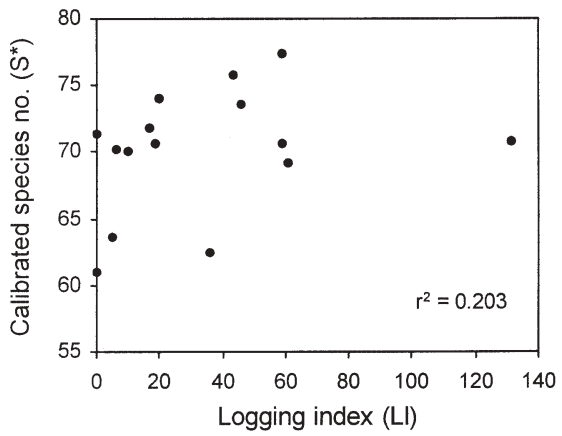

Figure 4. Correlation between logging index and calibrated species richness ( $\mathrm{S}^{*}$ ) for 15 forests in Western Region, Ghana: (a) mist-net data, (b) transect-walk data.

a)

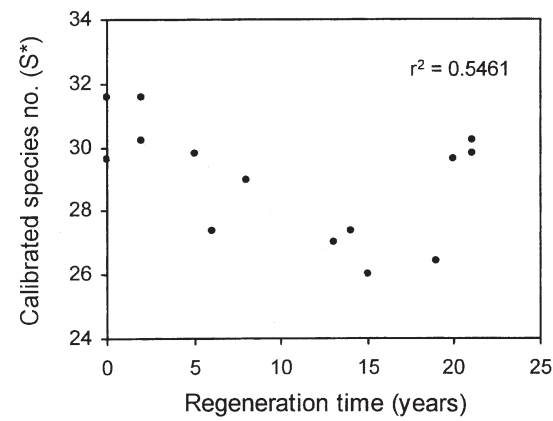

b)

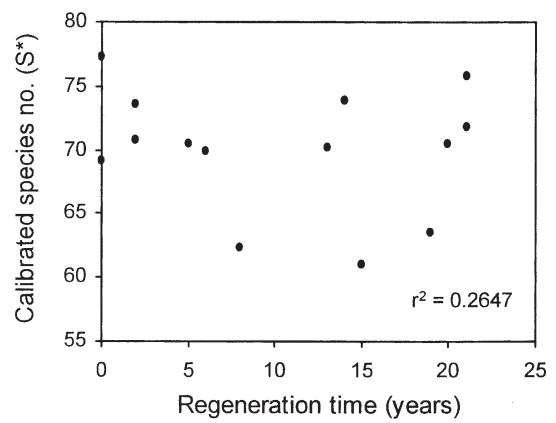

Figure 5. Correlation between regeneration time and calibrated species richness ( $S^{*}$ ) for 15 forests in Western Region, Ghana: (a) mist-net data, (b) transect-walk data.

a)

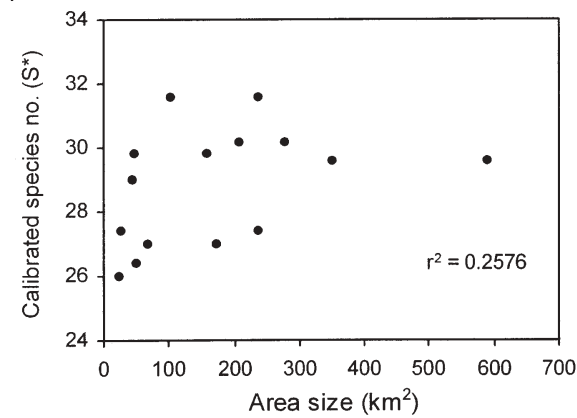

b)

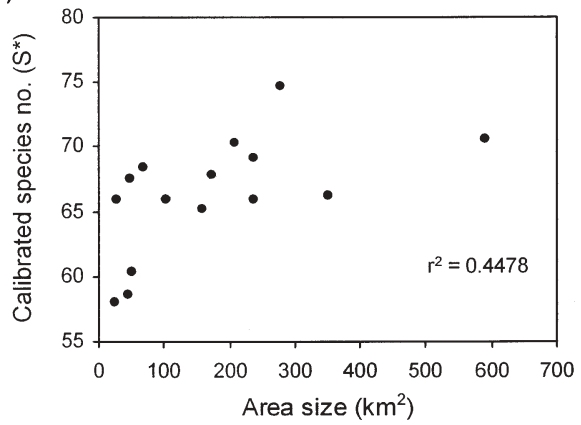

Figure 6. Correlation between size of area and calibrated species richness $\left(\mathrm{S}^{*}\right)$ for 15 forests in Western Region, Ghana: (a) mist-net data, $(b)$ transect-walk data.

preference for forest edges, clearings and farmland, and (3) generalists (Gs), equally abundant in all habitats. This categorization reflected an arbitrary consensus analysis of preference data in Grimes (1987) and Thiollay (1985) together with my own experiences (Holbech 1992). 
a)

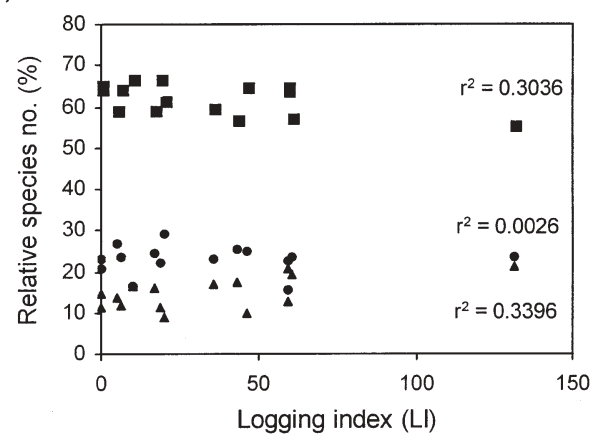

b)

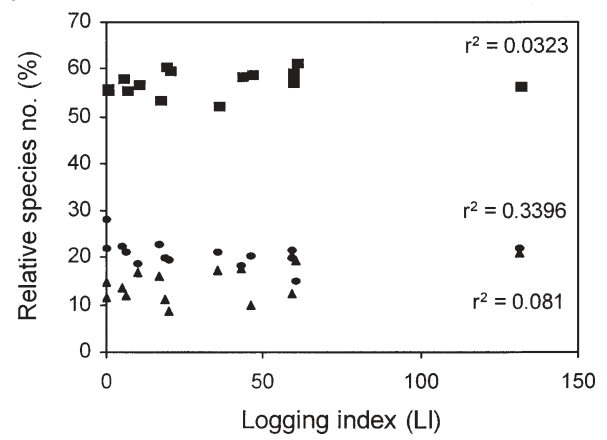

Figure 7. Correlation between logging intensity (LI) and relative species number of forest obligates (Fs n), open-land (Os s) and generalist (Gs l) species for 15 forests in Western Region, Ghana: (a) mist-net data, $(b)$ transect-walk data.

Mist-net data showed that the percentage of understorey Fs gradually decreased with increasing logging intensity (Figure 7a), whereas the opposite relation was observed for Os. The percentage of Gs was almost constant. In the most heavily logged forest (Bura: 3.75 trees per ha) the Fs make up c. $55 \%$ and Os close to $20 \%$. In the virgin forest (Jema-Assemkrom) these figures were c. $65 \%$ and c. 10\%. The positive slope on the linear Os curve is $10 \%$ higher than the negative slope on the linear Fs curve (Figure 7a), indicating that moderately logged forests "lost" fewer Fs than the Os they "gained". Thus, these forests could maintain a relatively high fraction of Fs and at the same time support many Os. As a result, overall species richness was higher than in unlogged or lightly logged forests. It is remarkable that one heavily logged forest (Fure: 1.71 trees per ha) and two moderately logged forest (Subri: 1.50 trees per ha; Tano Nimri: 1.04 trees per ha) logged forests had a similar Fs-Os distribution as the virgin site, and that four or five less intensively logged sites had a lower Fs fraction compared with these three. Transect data showed no clear trends in Fs-Os pattern, though tended towards an increased percentage of Fs and Os but a decreased percentage of Gs with increased logging intensity (Figure $7 \mathrm{~b}$ ).

\section{Distribution of rare forest residents with high conservation importance}

The comprehensive and detailed Ghanaian status list by Grimes (1987) was applied to select species of high conservation importance in Ghana and the Upper Guinea Forest. A total of 21 of the 86 mist-netted species (25 of 130 for transects) are rare or endangered in Ghana and restricted to closed primary forest (Appendix). Relative abundance of each species in all forests reflected the relative rarity of a species. Each species was then categorized according to a rarity score (RS) of 1 to 6 points: RS $6 \sim<2$ captures or records per $10,000 \mathrm{n}-\mathrm{m}$-h or $10 \mathrm{~km}$ walked transect (i.e. endangered); RS $5 \sim 2-5$ (vulnerable); RS $4 \sim 6$-10 (very rare); RS $3 \sim$ 11-20 (rare); RS $2 \sim 21-60$ (uncommon); $\mathrm{RS}_{1} \sim>6$ o (locally uncommon). This codex should not be compared with any regionally accepted status terminology (e.g. IUCN/SSC Red Data List), but used merely to assess the implications of logging and fragmentation on species that are rare in Ghana. 
By multiplying the relative abundance with species specific RS points for all species recorded in each forest, a total score makes up the overall conservation score index (CSI) for each forest. The CSI expresses how important a forest is for maintaining viable populations of these key species, i.e. the conservation importance of a forest.

There was no significant correlation between logging index (LI) and CSI values for either mist-net or transect data (Tables 5, 6), suggesting that logging at these densities had no direct implications for the distribution and abundance of species important

Table 5. Species number and overall relative abundance (in parentheses) of conservation-important species in six rarity score categories (RS: $1-6)$, and the calculated conservation score index $\left(\mathrm{CSI}^{\mathrm{b}}\right)$ for each forest, based on mist-net data.

\begin{tabular}{lllllllrr}
\hline Forest (size $\downarrow)$ & RS $=1$ & RS $=2$ & RS $=3$ & RS $=4$ & RS $=5$ & RS =6 & Total & CSI \\
\hline Subri & $3(28.2)$ & $1(1.8)$ & $3(4.8)$ & $2(2.4)$ & $1(0.6)$ & $1(0.6)$ & $11(38.4)$ & 62.4 \\
Ankasa & $3(29.5)$ & $1(11.6)$ & $4(7.4)$ & $2(2.0)$ & $2(1.6)$ & $3(2.4)$ & $15(54.5)$ & 105.3 \\
Boin & $3(18.3)$ & $1(0.5)$ & $5(3.1)$ & $2(0.9)$ & - & $1(0.2)$ & $12(23.0)$ & 33.4 \\
Yoyo & $3(18.4)$ & $1(1.2)$ & $3(4.8)$ & - & - & - & $7(24.4)$ & 35.2 \\
Draw & $3(20.3)$ & $1(1.2)$ & $5(6.0)$ & $3(3.9)$ & - & $2(0.9)$ & $14(32.3)$ & 61.7 \\
Tano Nimri & $3(25.2)$ & $1(1.3)$ & $4(6.1)$ & $1(1.3)$ & - & $1(0.4)$ & $11(34.3)$ & $53 \cdot 7$ \\
Dadiaso & $3(10.4)$ & - & $3(2.5)$ & - & $1(0.5)$ & - & $7(13.4)$ & 20.4 \\
Fure & $3(11.5)$ & $1(1.0)$ & $3(2.6)$ & $1(0.6)$ & $1(0.3)$ & - & $9(16.0)$ & 25.2 \\
Bura & $3(14.9)$ & $1(0.6)$ & $4(4.9)$ & $1(0.6)$ & $1(0.6)$ & - & $10(21.6)$ & 36.2 \\
Jema-Assemkrom & $3(14.1)$ & - & $3(1.5)$ & $1(0.5)$ & - & - & $7(16.1)$ & 20.6 \\
Cape Three Point & $3(14.2)$ & - & $2(7.5)$ & $2(1.8)$ & $1(1.2)$ & - & $8(24.7)$ & 49.9 \\
Mamiri & $3(21.0)$ & $1(0.6)$ & $1(0.6)$ & $1(0.6)$ & $1(0.6)$ & $2(1.2)$ & $9(24.6)$ & 36.6 \\
Neung North & $2(3.8)$ & $1(1.9)$ & $3(4.8)$ & $1(1.0)$ & - & - & $7(11.5)$ & 26.0 \\
Ebi & $3(13.0)$ & $1(1.6)$ & $4(4.1)$ & $3(4.8)$ & - & $1(1.0)$ & $12(24.5)$ & 53.7 \\
Disue & $3(13.2)$ & - & $3(3.7)$ & - & $1(0.9)$ & - & $7(17.8)$ & 28.8 \\
Total species & 3 & 1 & 5 & 3 & 2 & 7 & 21 & \\
\hline
\end{tabular}

${ }^{\mathrm{a}} \mathrm{N}_{\text {fre, }}$ bird captures per 10,000 n-m-h.

${ }^{\mathrm{b}} \mathrm{CSI}=\Sigma\left(\mathrm{N}_{\text {fre }} \times \mathrm{RS}\right)$.

Table 6. Species number and overall relative abundance (in parentheses) of conservation-important species in six rarity score categories (RS: $1-6)$, and the calculated conservation score index $\left(\mathrm{CSI}^{\mathrm{b}}\right)$ for each forest, based on transect data.

\begin{tabular}{llllllllr}
\hline Forest (size $\downarrow)$ & RS $=1$ & RS $=2$ & RS $=3$ & RS $=4$ & RS $=5$ & RS =6 & Total & CSI \\
\hline Subri & $6(61.7)$ & $5(26.7)$ & & $1(2.5)$ & $1(0.8)$ & $1(0.8)$ & $14(92.5)$ & 133.9 \\
Ankasa & $6(54.9)$ & $5(19.0)$ & $1(10.9)$ & $3(2.7)$ & $2(1.0)$ & $1(0.3)$ & $18(88.8)$ & 143.2 \\
Boin & $6(50.1)$ & $3(10.2)$ & $2(4.1)$ & $3(1.9)$ & $3(2.5)$ & $1(0.2)$ & $18(69.0)$ & 104.1 \\
Yoyo & $6(55.6)$ & $3(5.1)$ & $1(5.1)$ & $1(0.5)$ & $2(2.8)$ & - & $13(69.1)$ & 97.1 \\
Draw & $6(59.4)$ & $4(16.6)$ & $1(0.3)$ & $3(4.0)$ & $2(1.0)$ & $1(1.0)$ & $17(82.3)$ & 120.5 \\
Tano Nimri & $6(81.8)$ & $5(22.2)$ & - & $2(1.7)$ & $1(1.1)$ & - & $14(106.8)$ & 138.5 \\
Dadiaso & $6(84.5)$ & $2(6.2)$ & $1(2.7)$ & $1(1.9)$ & $1(0.4)$ & $2(1.2)$ & $13(96.9)$ & 121.8 \\
Fure & $6(59.2)$ & $4(3.3)$ & - & $2(2.5)$ & $2(0.8)$ & $1(0.4)$ & $15(66.2)$ & 82.2 \\
Bura & $6(57.0)$ & $3(6.3)$ & - & $1(1.6)$ & - & $1(0.8)$ & $11(65.7)$ & 80.8 \\
Jema-Assemkrom & $6(86.3)$ & $5(28.3)$ & - & $3(4.4)$ & - & - & $14(119.0)$ & 160.5 \\
Cape Three Point & $4(43.8)$ & $4(28.1)$ & - & $2(1.8)$ & - & - & $10(73.7)$ & 107.2 \\
Mamiri & $6(48.4)$ & $2(4.7)$ & - & - & $1(1.6)$ & - & $9(54.7)$ & 65.8 \\
Neung North & $2(4.8)$ & $1(3.6)$ & - & - & - & - & $3(8.4)$ & 12.0 \\
Ebi & $5(48.6)$ & $3(18.8)$ & - & $1(0.7)$ & - & - & $9(68.1)$ & 89.0 \\
Disue & $6(32.1)$ & $1(2.7)$ & $1(10.7)$ & - & $1(2.7)$ & - & $9(48.2)$ & 83.1 \\
Total species & 6 & 5 & 2 & 4 & 4 & 4 & 25 & - \\
\hline
\end{tabular}

${ }^{\mathrm{a}} \mathrm{N}_{\text {fre, }}$ bird records per $10 \mathrm{~km}$ walk.

${ }^{b} \mathrm{CSI}=\mathrm{S}\left(\mathrm{N}_{\text {fre }} \times \mathrm{RS}\right)$. 
a)

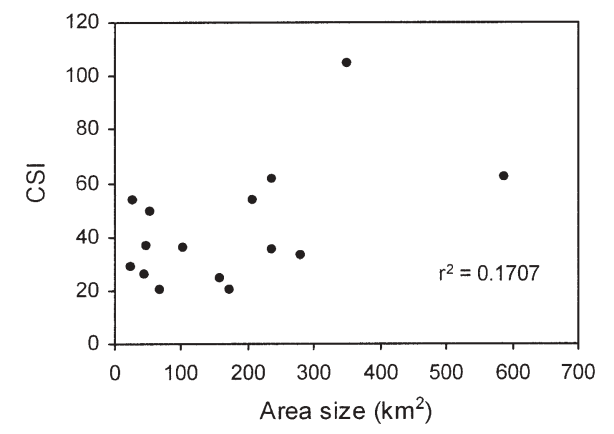

b)

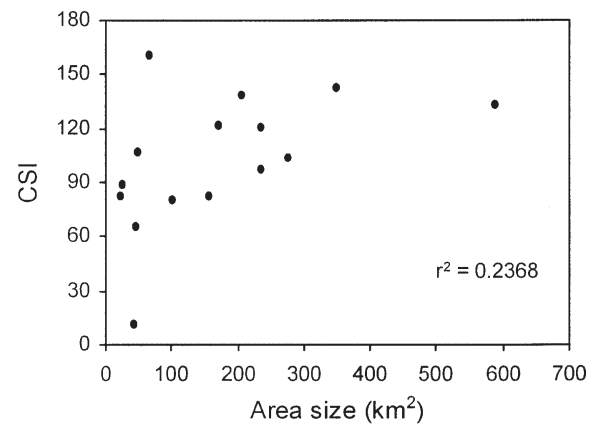

Figure 8. Correlation between size of area and conservation score index (CSI) for 15 forests in Western Region, Ghana: $(a)$ mist-net data, $(b)$ transect-walk data.

to conservation recorded by this study. Whereas the positive correlation between CSI and area (Figure 8a) for mist-net data was significant (four-way ANOVA-test model: $F=7.22, P<0.0249, \mathrm{df}=1$ ), a less clear pattern was derived from transect data (Figure $8 \mathrm{~b}$ ). This suggested area was the principal factor for maintaining populations of species important to conservation, particularly where understorey birds are concerned.

For both data sets, four forests seemed to be outstanding in terms of conservation importance $\left(\mathrm{CSI}_{\text {net }}>60\right.$ and $\left.\mathrm{CSI}_{\text {transect }}>100\right)$ : Ankasa, Draw, Tano and Subri. These were all large reserves $\left(>200 \mathrm{~km}^{2}\right)$ adjacent to other large forest areas. Logging intensity has been moderate or heavy in Draw, Tano and Subri (LI $=45-60 \sim 1.0-1.6$ trees per hectare), whereas Ankasa was only lightly logged during the early 1960s up to the mid-1970s. At the other end of the scale, one forest was remarkably poor: Neung North $\left(\mathrm{CSI}_{\text {net }}=26\right.$ and $\left.\mathrm{CSI}_{\text {transect }}=8\right)$, which was comparatively small $\left(45.0 \mathrm{~km}^{2}\right)$, distant from any nearby forest $(3-4 \mathrm{~km})$, and had been logged heavily (LI $=35.75 \sim 1.43$ trees per hectare). Moreover, part of Neung North had been converted to an exotic tree-plantation. In comparison, the other small and isolated forest-island, Cape Three Point, had relatively high CSI values. Cape Three Point was almost virgin, indicating that isolated small forests can be relatively more susceptible to logging than larger ones. Correspondingly, large $\left(>200 \mathrm{~km}^{2}\right)$ heavily logged forests were equally good or even better as avian conservation areas compared with smaller $\left(<50 \mathrm{~km}^{2}\right)$, lightly logged or even unlogged forests.

The virgin site Jema-Assemkrom had the highest CSI for transect data, but secondlowest CSI for mist-net data. This inconsistency between the two data sets could not be readily explained by census biases, but indicated that mist-netting alone is not a complete census method for evaluating understorey bird diversity. The two census methods applied in this study complemented each other well, as regards both their advantages and biases. The importance, however, of using mist-nets to reveal local abundance of rather silent and unobtrusive rare forest obligates is exemplified by three understorey species — Blue-headed Bee-eater Merops müelleri, Forest Scrubrobin Cercotrichas leucosticta and Grey Ground Thrush Turdus princei - the only records of which came from single mist-netting captures in Ankasa. That these three species were uniquely recorded in Ankasa, also indicated the importance of leaving large areas of forests almost untouched in order to conserve vulnerable and rare bird species. 


\section{Discussion}

Selective logging in Ghana: a unique sustainable practice or high avian resilience?

The preliminary unpublished findings from the Bia moist rainforest (Holbech 1992) that selective logging in Ghana had moderate and rather short-term reversible effects on vegetation structure and avifauna, were consistent with those of this study from the moist and wet evergreen forest zones in south-west Ghana. In both studies logging seemed to increase overall species diversity during the first $2-5$ years following logging under moderate extraction levels up to $c .3$ trees per ha. The average logging intensity in both studies was $c$. 1 tree per ha, and the canopy disruption estimated to range between $10 \%$ and $20 \%$.

The question now arises whether, from a bird conservation point of view, the positive indications from Ghana reflect a highly selective logging practice with good signs of sustainability, or a uniquely high resilience of Ghanaian (Upper Guinea) forest birds. Tropical avifauna is least affected, i.e. birds are more resilient, in the Neotropics and Indo-Malayan region; they are least resilient in East Africa (Fjeldså 1994). Danielsen (1997) discussed whether this difference in resilience is related to the long-term instability of the regions, and found some evidence by comparing several comprehensive studies. However, he concluded that a critical comparative analysis is presently limited by methodological inconsistency, site-specific, structural and historical parameters, lack of suitable controls and incomplete information on logging intensity and regeneration time.

In this study, forest habitat generalists made up over $20 \%$ of species, a similar proportion preferring open-land and edge habitats. Moreover, in a parallel study to this, several species hitherto termed forest obligates by Grimes (1987) were found frequently in modified forest habitats such as exotic tree plantations, abandoned cocoa farms and secondary forest (Holbech 1996). These included species associated with army ants, e.g. White-tailed Ant Thrush Neocossyphus poensis, Fire-crested Alethe Alethe diademata, Timaliidae and Criniger species, reported to be particularly vulnerable to disturbances elsewhere in the tropics (Willis 1979, Karr 1982, Wong 1986, Dranzoa 1998, Johns 1989). Similarly, some species showed a strong preference for closed-canopy forest as well as open land and forest edge in the Bia moist rainforest, e.g. African Pied Hornbill Tockus fasciatus, Blue-throated Roller Eurystomus gularis, Yellow-billed Barbet Trachyphonus purpuratus, Red-headed Malimbe Malimbus rubricollis and Grey-crowned Negro Finch Nigrita canicapilla (Holbech 1992).

The relatively high proportion of habitat generalists in Ghana certainly indicates a high degree of resilience and adaptability of the forest avifauna compared with East Africa. The Upper Guinea Forest, of which Ghana constitutes the easternmost part, has undergone several unstable periods of climatically related forest-savannah mosaic ecotone reductions (Fjeldså 1994), which would have led many adaptable species to be robust to a variable climate and forest cover. These species are likely to be more resilient to logging disturbances and fragmentation. A typical example is Olive Sunbird Nectarinia olivacea, living equally well in forest interior and urban garden habitats. Other species are also known to migrate seasonally between the savannah and forest zones, e.g. White-throated Bee-eater Merops albicollis and Splendid Glossy Starling Lamprotornis splendidus, both of which have been observed in the Ankasa rainforest as well as well-wooded garden habitats around Accra.

However, it is inappropriate to conclude that the moderate consequences of selective logging in Ghana reflect only a unique resilience of Upper Guinea Forest birds. The 
fact that logging is more selective and less destructive on the forest structure in Ghana, compared with logging practices elsewhere, should be highlighted. Several studies from the Neotropics and Indo-Malayan region conclude that logging is unselective with a 40-50\% canopy disruption and loss of understorey vegetation at extraction levels of 3-8 trees per ha, equivalent to as much as 18-25 trunks (small to medium-sized Dipterocarpus) or $24 \mathrm{~m}^{3}$ (Uhl and Guimaraes Vieira 1989, Johns 1988, 1991, Lambert 1992, Thiollay 1992). The extraction levels in African tropical forests are generally lower, due mainly to a lower density of marketable timber species (Putz et al. 2001). In Uganda, "selective" logging removes up to 7.4 trees per ha $\left(\sim 21 \mathrm{~m}^{3}\right)$, resulting in as much as $62 \%$ canopy destruction (Dranzoa 1998). In comparison, the average extraction level in Ghana moist and evergreen forest is only 1.5 trees per ha, equivalent to two trunks of $10 \mathrm{~m}^{3}\left(\sim c .20 \mathrm{~m}^{3}\right)$, and only $20 \%$ of the ground area is affected (Hawthorne 1993, Adams et al. 1994). The Ghanaian selection and extraction system is obviously less destructive.

In Ghana, hauling roads, skid tracks and loading bases are restricted by upper limits on size and distribution, just as the selection criteria are based on detailed stock mapping and species/area-specific minimum girth limits, similar to the reduced-impact logging (RIL) pilot systems of Sabah, Malaysia (Pinard and Putz 1996). Moreover, at least $30-60 \%$ of felled mature stock is left for forest regeneration purposes in the 40-year logging cycle, introduced in 1991. In comparison, most other forestry practices in West and Central Africa adopt almost 100\% utilization of mature stand with a 40- to 50-year cycle (Osho 1995). Low-extraction selective logging also occurs in the Lopé Reserve, Gabon, where a maximum 2 trees per hectare are extracted. In Lopé the reduction of basal area and canopy was estimated at respectively $20.6 \%$ and $10 \%$, and only $10 \%$ and $6 \%$ of lost trees derive from felling damage and extraction operations, respectively (White 1994a). Unfortunately no data on avifaunal impacts are recorded from Lopé, although some data on large mammals exist (White 1994b).

The Ghanaian logging model may serve as a rough guideline for a more sustainable tropical logging industry to be developed and implemented globally. However, the findings and recommendations from Ghana may only be specific to the Upper Guinea forest region, as bird resilience varies greatly among the continents and regions within. Hence, lower limits applicable for sustainable extraction levels in Ghana, which also pay attention to bio-geographical parameters (forest size and isolation), may be upper limits or even unsustainable elsewhere in the tropics.

Finally, the results from this study and from Bia (Holbech 1992) are based on data from only moist and wet evergreen forest sub-types in Ghana. The situation in the drier parts of the forest zone (dry semi-deciduous sub-zones) is markedly different, where logging is reported to be very intensive, paving the way for heavy colonization of the invasive weed Chromolaena odorata, which facilitates the spread of forest fires (Hawthorne and Abu-Juam 1993). Sustainable selective logging practices in these areas may require specific sustainability implications to achieve conservation objectives of maintaining the unique forest structure and biodiversity.

\section{Present state of knowledge for Ghana and logging recommendations}

This comprehensive study has considered four independent disturbance parameters in the sustainability evaluation of conservation importance (CSI), allowing quite robust and quantitative recommendations on area-specific sustainable extraction levels. 
Table 7. Recommendations on upper limits of extraction level and road entry points, as well as lower limits on logging cycle, according to forest size and isolation.

\begin{tabular}{|c|c|c|c|c|c|c|}
\hline \multirow[t]{2}{*}{ Limits } & \multicolumn{3}{|c|}{ Isolated forests $\left(\mathrm{km}^{2}\right)$} & \multicolumn{3}{|c|}{ Inter-linked forests $\left(\mathrm{km}^{2}\right)$} \\
\hline & $<50^{\mathrm{a}}$ & $50-200$ & $>200$ & $<50$ & $50-200$ & $>200$ \\
\hline Extraction (trees ha-1) & 0.5 & 1.0 & 2.0 & 1.0 & 2.0 & 3.0 \\
\hline Cycle (years) & $>100$ & 75 & 50 & 100 & 75 & 50 \\
\hline Road entry points & 1 & 2 & 3 & 1 & 2 & 3 \\
\hline
\end{tabular}

${ }^{a}$ Virgin forests should remain unlogged.

Bird communities of large forest areas interlinked by significant corridors of forest in good condition, can stand higher logging intensities than small forests which are completely isolated as islands or inadequately linked to other nearby forests by poor forest environments (young secondary forest or open farmland). I have made appropriate recommendations on limits of logging extraction, road entry points (upper) and regeneration cycle (lower) for wet evergreen, moist evergreen and moist semideciduous sub-types in the Ghana high forest zone (Table 7). It should be emphasized that very small $\left(<50 \mathrm{~km}^{2}\right)$ virgin forest islands should not be logged at all, because virgin forests in Ghana are becoming increasingly scarce.

Apart from the area-specific recommendations on appropriate upper/lower limits on extraction levels, road entry and regeneration cycle, it is crucial that interior core areas be set aside as unlogged biodiversity conservation areas in each forest. The percentage of such zones inevitably needs to be larger in small or narrow forests than in large bulky forests, in order to mitigate edge effects (climatic instability and human activities). Edge effects have recently been shown to affect a forest bird community at least $400 \mathrm{~m}$ from a 15 ha clearing in the Budongo forest of Uganda, a forest that has a high species overlap with Ghanaian moist and evergreen forests. It is also important that large hauling roads and loading stations are minimized and spaced in such a way that facilitate free movement of edge-shy forest obligates and other canopy-dependent animals. Hence, for at least every $\mathrm{I} \mathrm{km}$ of hauling roads, a minimum continuous stretch of $100 \mathrm{~m}$ (10\%) continuous canopy should be maintained across the road. Finally, when felling trees on roads and stations care should be taken to land these trees in already disturbed areas (towards the middle of roads and clearings).

\section{Acknowledgements}

A PhD grant provided by the Council for Development Research, Danida (no. 104.Dan.8/606), and supported by the University of Copenhagen, Denmark (UCD) and University of Ghana, Legon (UGL) made the study possible. I wish to express sincere gratitude to the Ghana Wildlife Division (GWD) and Ghana Forestry Commission (Ministry of Lands and Forestry) for granting research and entry permits to protected areas in Ghana. Particular appreciation for invaluable field assistance from my GWD-counterpart, Senior Wildlife Protection Officer, Mr Joseph Amponsah, as well as helpful supervision and encouragement by Dr Yaa Ntiamoa-Baidu, Department of Zoology (UGL), must be given. Constructive criticism and review of manuscript were kindly provided by Dr Phil. Jon Fjeldså, Zoological Museum of Denmark (UCD). Johnny Nielsen assisted with PC programming and graphics, and Francis Hurst with language editing. 


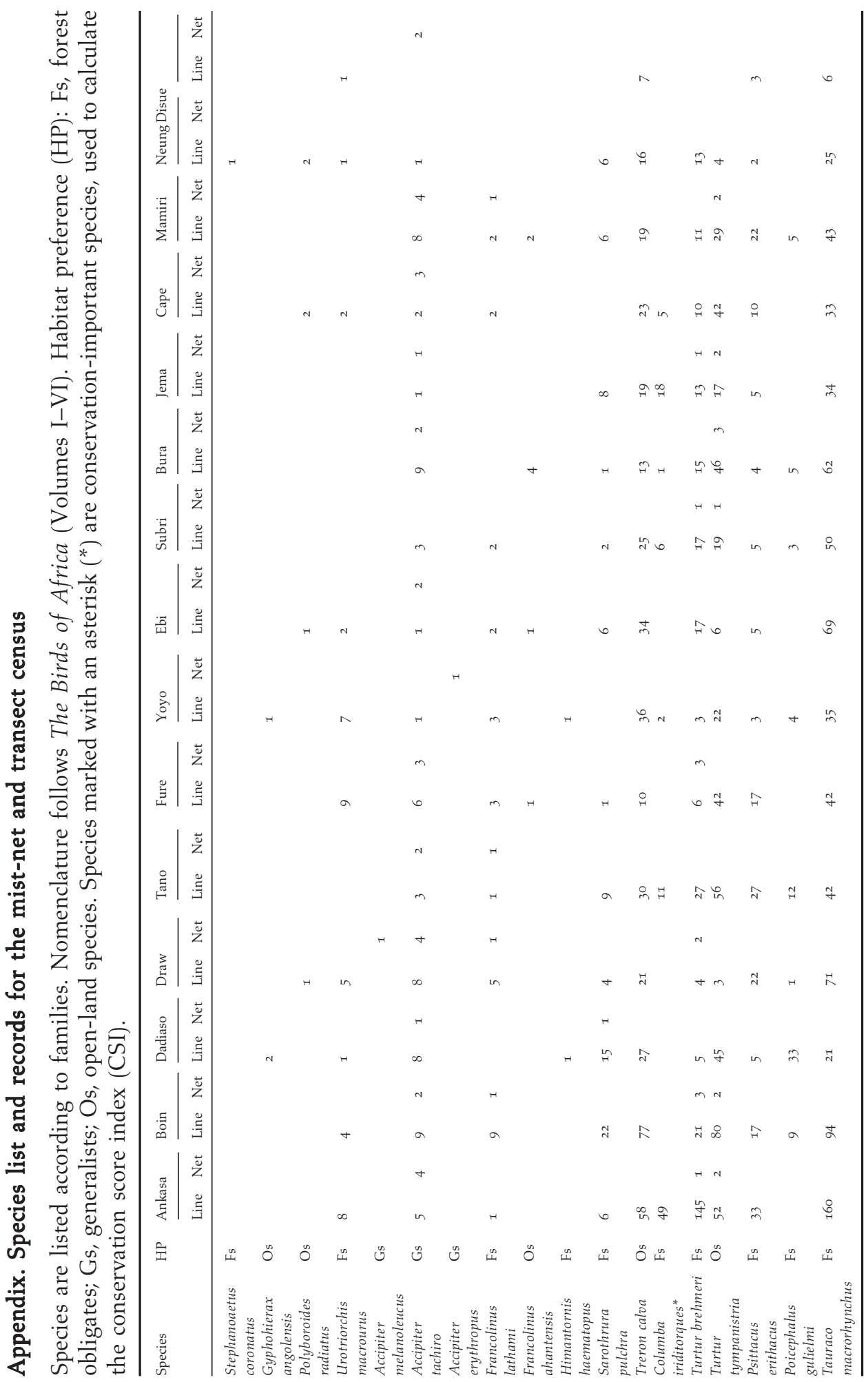




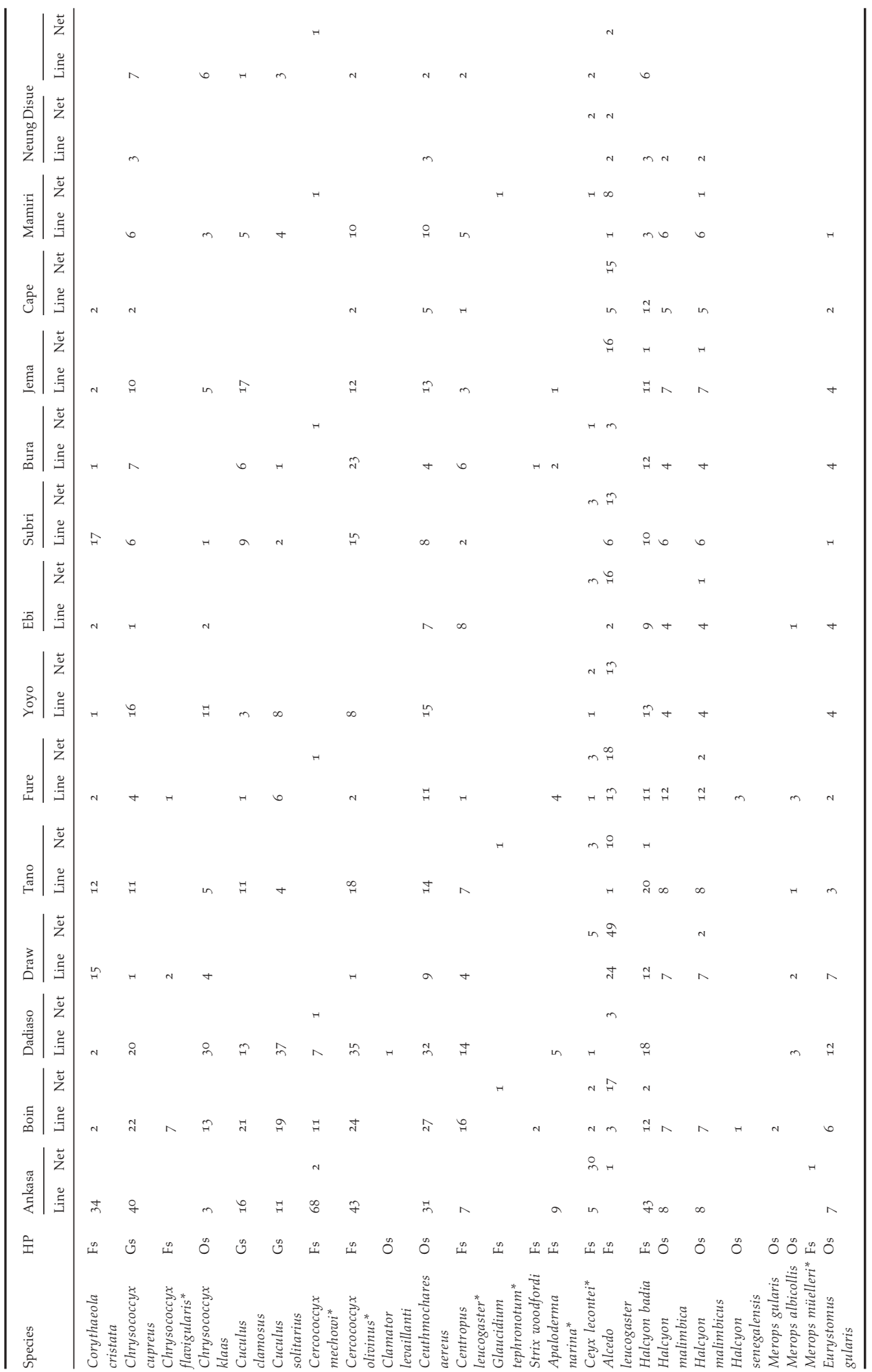




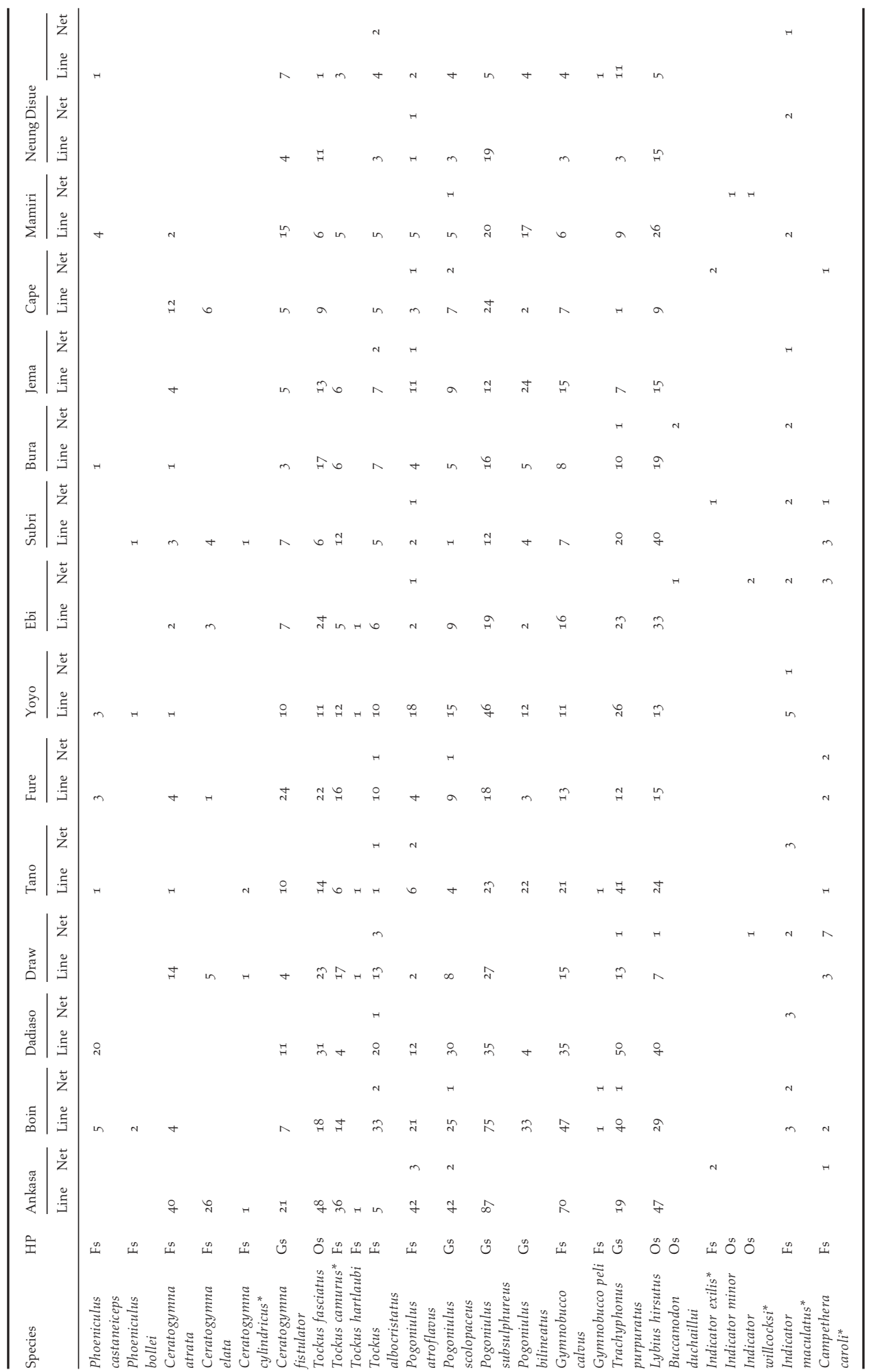




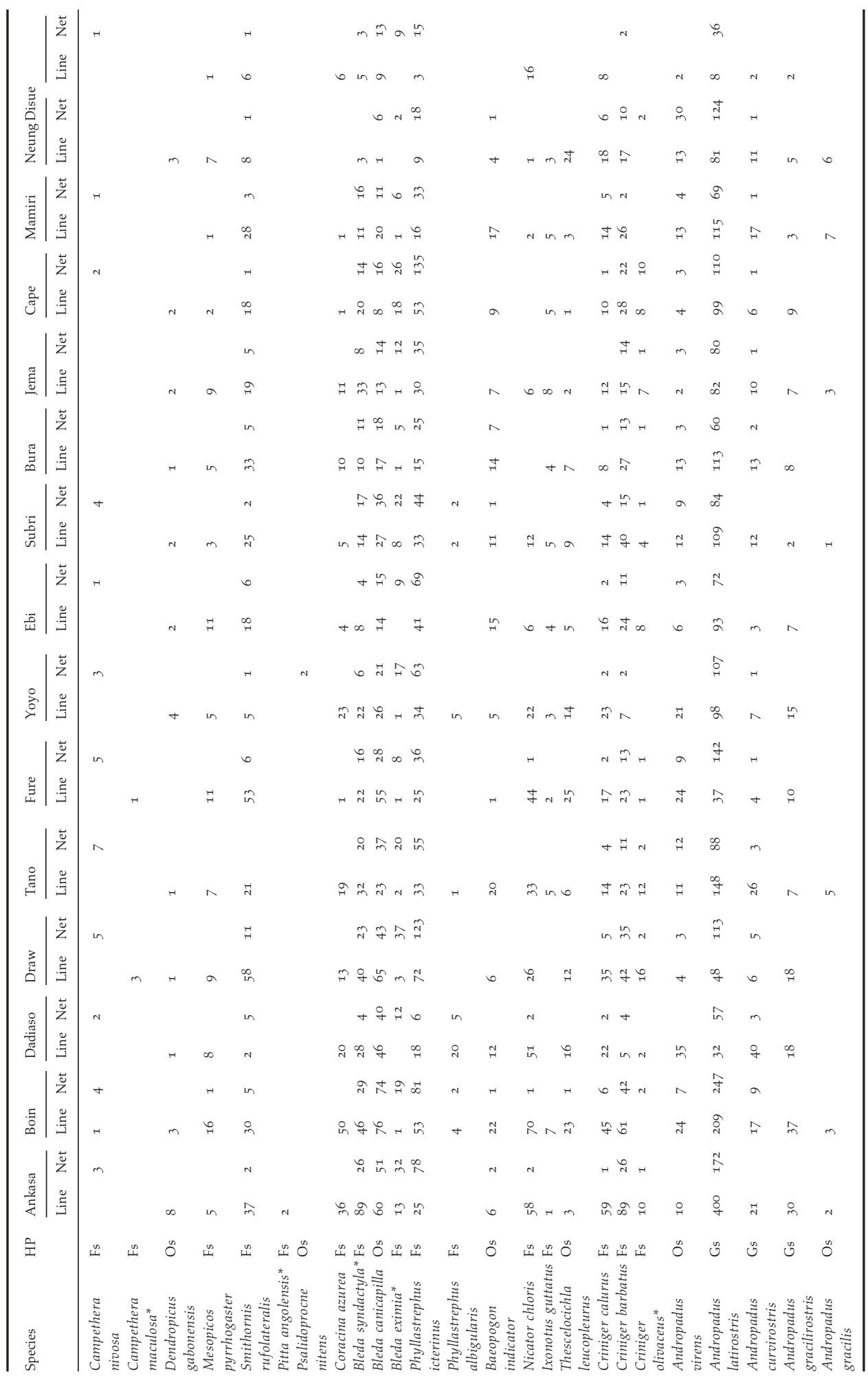




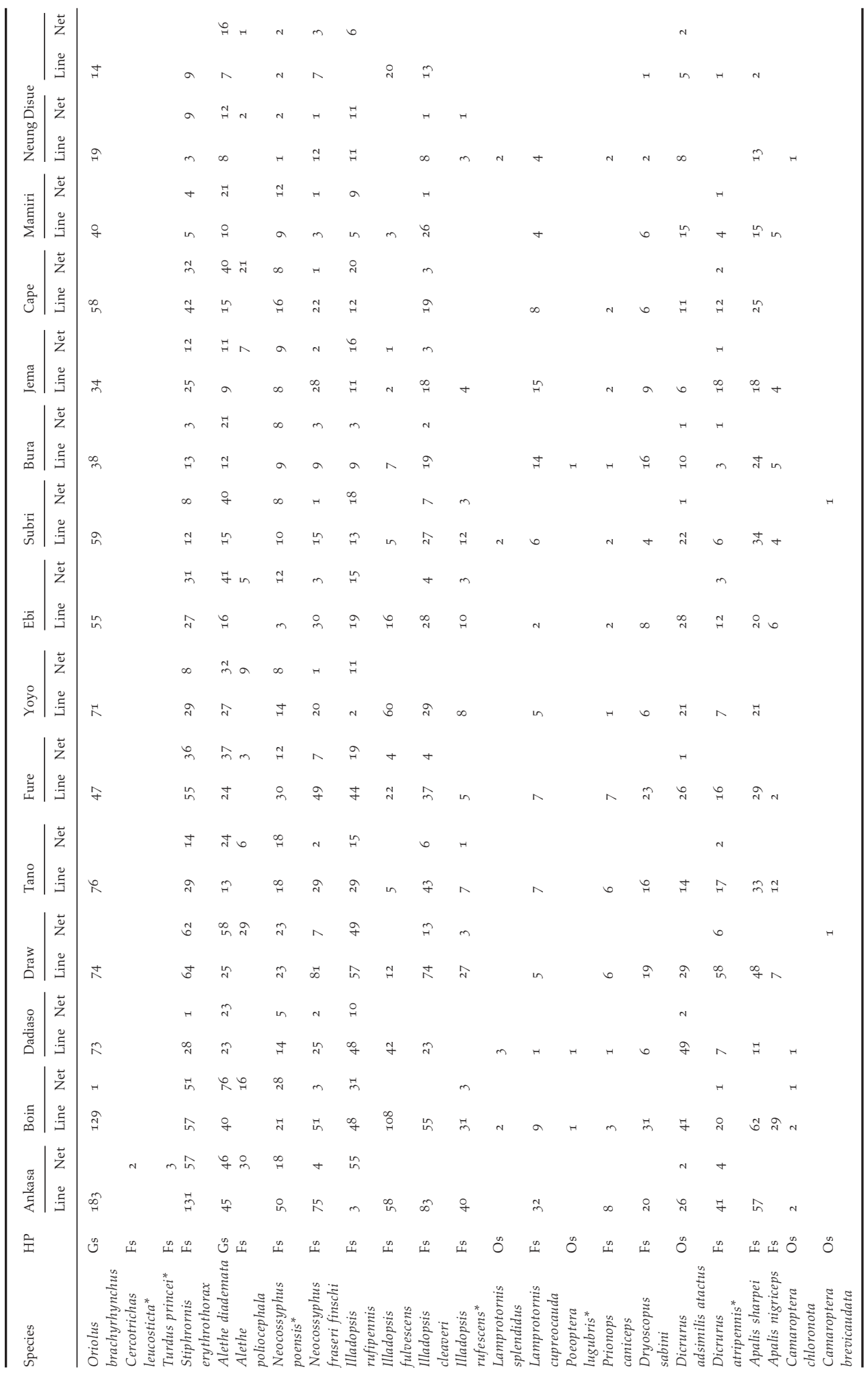




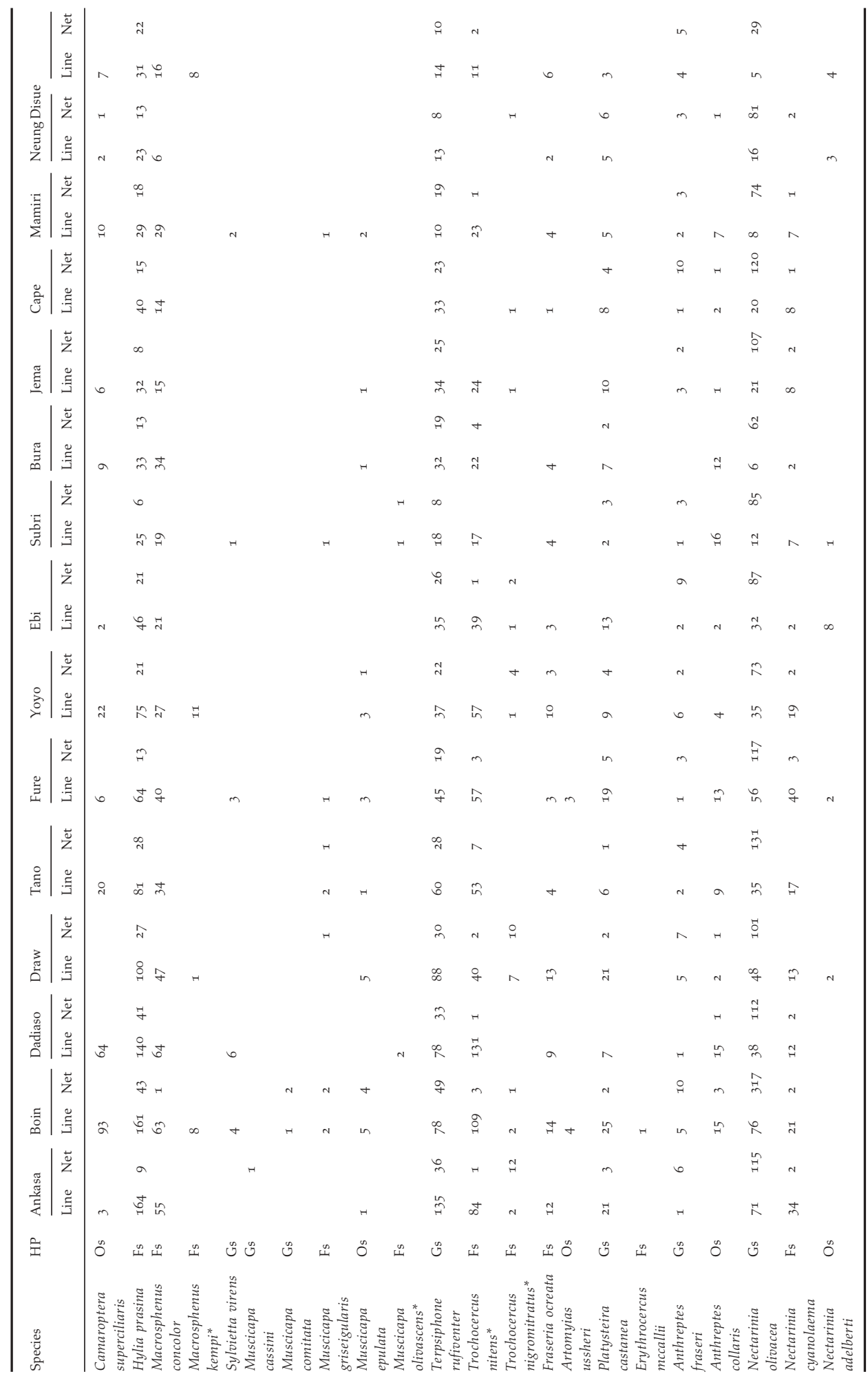




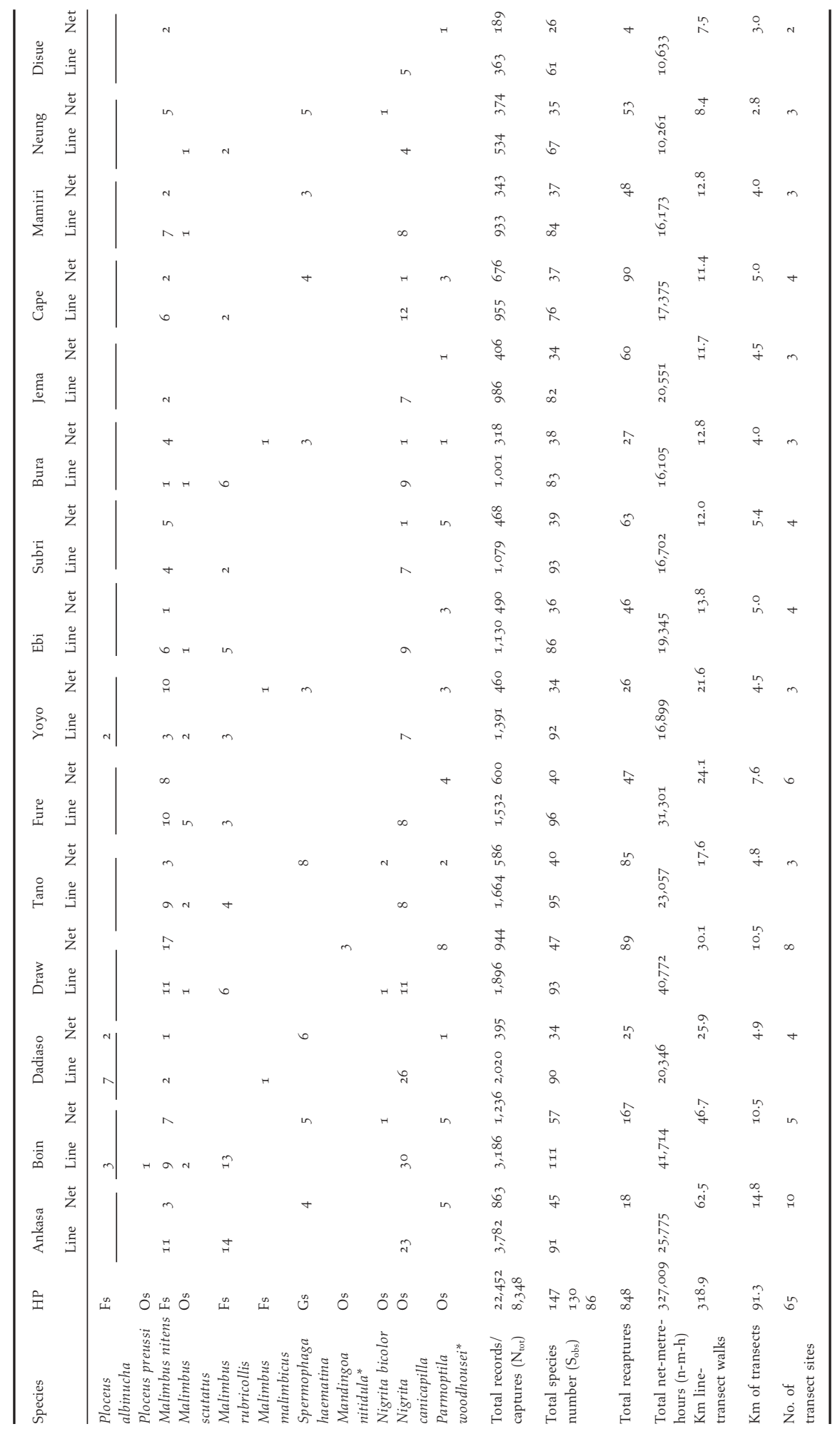




\section{References}

Adams, A. R., Foli, E. G. and Ofosu-Asiedu, A. (1994) Logging intensity and its effect on the maintenance of forest values for sustained growth of the timber industry. Pp. 8-1o in Forest land use options: conflicts and solutions. Kumasi: Forest Research Institute of Ghana, Ghana Forestry Department.

Aleixo, A. (1999) Effects of selective logging on a bird community in the Brazilian Atlantic forest. Condor 101: 537-548.

Bell, H. L. (1982) A bird community of lowland rainforest in New Guinea. 4. Birds of secondary vegetation. Emu 82: 217-224.

Bierregaard, R. O. and Lovejoy, T. E. (1989) Effects of isolation of understory birds communities in Amazonian forest fragments. Acta Amazonica 19: 215-241.

Dale, S., Mork, K., Solvang, R. and Plumptre, A. J. (2000) Edge effects on the understory bird community in a logged forest in Uganda. Conserv. Biol.14: 265-276.

Danielsen, F. (1997) Stable environments and fragile communities: does history determine the resilience of avian rain-forest communities to habitat degradation? Biodiv. Conserv. 6: 423-433.

Datta, A. (1998) Hornbill abundance in unlogged forest, selectively logged forest and a forest plantation in Arunachal Pradesh, India. Oryx 32: 285-294.

Dranzoa, C. (1993) Birds of fragmented forest areas in southern Uganda. Proc. VIII Pan-African Orn. Congr.: 334-340.

Dranzoa, C. (1995) Bird populations of primary and logged forests in Kibale Forest National Park, Uganda. PhD thesis, Makekere University, Kampala, Uganda.

Dranzoa, C. (1998) The avifauna 23 years after logging in Kibale National Park, Uganda. Biodiv. Conserv. 7: 777-797.

Driscoll, P. V. and Kikkawa, J. (1989) Bird species diversity of lowland tropical rain forest of New Guinea and Northern Australia. Pp. 123-152 in M. L. Harmelin-Vivien and F. Bourlière, eds. Vertebrates in complex tropical systems. New York: Springer (Ecological studies no. 69).

Fanshawe, J. H. (1996) The effects of selective logging on the bird community of Arabuko Sokoke Forest, Kenya. PhD thesis. Abstract in Ibis 138: 372 .

Fjeldså, J. (1994) Geographical patterns for relict and young species of birds in Africa and South America and implications for conservation priorities. Biodiv. Conserv. 3: 207-226.

Fjeldså, J. (1999) The impact of human forest disturbance on the endemic avifauna of the Udzungwa Mountains, Tanzania. Bird Conserv. Int. 9: 47-62.

Fjeldså, J. and Rabøl, J. (1995) Variation in avian communities between isolated units of the Eastern Arc montane forests, Tanzania. Gerfaut 85: 3-18.

Ghana Forestry Department (1992) Logging manual for forest management in Ghana. Kumasi: Planning Branch.

Grieser Johns, A. (1996) Bird population persistence in Sabahan logging concessions. Biol. Conserv. 75: 3-10.

Grimes, L. G. (1987) The birds of Ghana. British Ornithologist Union.

Hall, J. B. and Swaine, M. D. (1976) Classification and ecology of closed canopy forest in Ghana. J. Ecol. 64: 913-951.

Hawthorne, W. D. (1993) Forest regeneration after logging: findings of a study in the Bia South Game Production Reserve, Ghana. ODA Forestry Ser. 3: 61 pp.

Hawthorne, W. D. and Abu-Juam, M. (1993) Forest protection in Ghana. ODA Report. Kumasi: Forestry Department Planning Branch.

Holbech, L. H. (1992) Effects of selective logging on a rain-forest bird community in western Ghana. Unpublished MSc thesis, Institute of Population Biology, Department of Zoology, University of Copenhagen.

Holbech, L. H. (1996) Faunistic diversity and game production contra human activities in the Ghana high forest zone: with reference to the Western Region. PhD thesis, Department of Population Biology, Zoological Institute, University of Copenhagen, Denmark. 
Johns, A. D. (1985) Selective logging and wildlife conservation in tropical rain-forest: problems and recommendations. Biol. Conserv. 31: 355-375.

Johns, A. D. (1986) Effects of selective logging on the ecological organisation of a peninsular Malaysian rainforest avifauna. Forktail 1: 65-79.

Johns, A. D. (1987) The use of primary and selectively logged rainforest by Malaysian hornbills (Bucerotidae) and implications for their conservation. Biol. Conserv. 40: 179-190.

Johns, A. D. (1988) Effects of "selective" timber extraction on rainforest structure and composition and some consequences for frugivores and folivores. Biotropica 20: 31-37.

Johns, A. D. (1989) Recovery of a peninsular Malaysian rainforest avifauna following selective timber logging: the first twelve years. Forktail 4: 89-105.

Johns, A. D. (1991) Responses of Amazonian rain forest birds to habitat modification. J. Trop. Ecol. 7: 417-437.

Johns, A. D. (1992) Vertebrate responses to selective logging: implications for the design of logging systems. Phil. Trans. R. Soc. Lond. B 335: 437-442.

Johns, A. D. (1995) Bird population persistence in Sabahan logging concessions: the importance of refuges. Biol. Conserv. 75: 3-10.

Karr, J. R. (1982) Avian extinction on Barro Colorado Island, Panama: a reassessment. Am. Nat. 119: 220-239.

Lambert, F. R. (1991) The conservation of fig eating birds in Malaysia. Biol. Conserv. 58: 31-40.

Lambert, F. R. (1992) The consequences of selective logging for Bornean lowland forest birds. Phil. Trans. R. Soc. Lond. B 335: 443-457.

Marsden, S. J. (1998) Changes in bird abundance following selective logging on Seram, Indonesia. Conserv. Biol. 12: 605-611.

Mason, D. (1996) Responses of Venezuelan understory birds to selective logging, enrichment strips, and vine cutting. Biotropica 28: 296-309.

Newmark, W. D. (1991) Tropical forest fragmentation and the local extinction of understory birds in the Eastern Usambara Mountains, Tanzania. Conserv. Biol. 5: 67-78.

Osho, J. S. A. (1995) Optimal sustainable harvest models for a Nigerian tropical rain forest. J. Env. Mgmt. 45: 101-108.

Owiunji, I. (2000) Changes in avian communities of Budongo Forest Reserve after 70 years of selective logging. Ostrich 71: 216-219.

Owiunji, I. and Plumptre, A. J. (1998) Bird communities in logged and unlogged compartments in Budongo Forest, Uganda. Forest Ecology and Management 108: 112-126.

Pinard, M. A. and Putz, F. E. (1996) Retaining forest biomass by reducing logging damage. Biotropica 28: 278-295.

Putz, F. E., Blate, G. M., Redford, K. H., Fimbel, R. and Robinson, J. (2001) Tropical forest management and conservation of biodiversity: an overview. Conserv. Biol. 15: 7-20.

Remsen, J. V. and Good, D. A. (1996) Misuse of data from mist-net captures to assess relative abundance in bird populations. Auk 113: 381-398.

Thiollay, J.-M. (1985) The West African forest avifauna: a review. ICBP Tech. Publ. 4: 171-186.

Thiollay, J.-M. (1992) Influence of selective logging on bird species diversity in a Guyanan rain forest. Conserv. Biol. 6: 47-63.

Thiollay, J.-M. (1997) Disturbance, selective logging and bird diversity: a Neotropical forest study. Biodiv. Conserv. 6: 1155-1173.

Uhl, C. and Guimaraes Vieira, I. C. (1989) Ecological impacts of selective logging in the Brazilian Amazon: a case study from the Paragominas region of the state of Para. Biotropica 21: 98-106.

White, L. J. T. (1994a) The effects of commercial mechanised selective logging on a transect in lowland rainforest in the Lopé Reserve, Gabon. J. Trop. Ecol. 10: 313-322.

White, L. J. T. (1994b) Biomass of rain forest mammals in the Lopé Reserve, Gabon. J. Anim. Ecol. 63: 499-512. 
Whitman, A. A., Hagan III, J. M. and Brokaw, N. V. L. (1998) Effects of selection logging on birds in Northern Belize. Biotropica 30: 449-457.

Willis, E. O. (1979) The composition of avian communities in remanescent woodlots in Southern Brazil. Papéis Avulsos de Zoologia, S. Paolo 33: 1-25.

Wilson, W. L. and Johns, A. D. (1982) Diversity and abundance of selected animal species in undisturbed forest, selectively logged forest and plantations in East Kalimantan, Indonesia. Biol. Conserv. 24: 205-218.

Wong, M. (1985) Understory birds as indicators of regeneration in a patch of selectively logged West Malaysian rain forest. ICBP Tech. Publ. 4: 249-263.

Wong, M. (1986) Trophic organisation of understory birds in a Malaysian Dipterocarp forest. Auk 103: 100-116.

LARS H. HOLBECH*

Department of Population Biology, Zoological Institute, University of Copenhagen, Universitetsparken 15,2100 Copenhagen Ø, Denmark (e-mail: l.holbech@ofir.dk)

${ }^{*}$ Current address: Ruten $111 D$, St., 2700 Brønshøj, Denmark

Received 24 January 2002; revision accepted 4 May 2004 